\title{
Too many boats chasing too few fish: The collapse of the Atlantic groundfish fishery and the avoidance of future collapses through free market environmentalism
}

\author{
Jacquelyn Rutherford
}

\author{
This manuscript was prepared under the supervision of Professor Glenn Fox, \\ Department of Food, Agricultural \& Resource Economics, Ontario Agricultural College.
}

\begin{abstract}
On July 2, 1992 Canada's fisheries minister banned cod fishing off the northeast coast of Newfoundland and off the southern coast of Labrador. Overestimated cod stocks creating exaggerated Total Allowable Catches, coupled with increased fishing capacity, lead to the depletion of the Atlantic cod fisheries. This crisis occurred in the context of strong government policy and management. The Atlantic cod and groundfish fisheries have yet to recover from this travesty of mismanagement. The state of the world's fisheries faces the same dismal fate as the Atlantic groundfish fishery, suffering from what has become known as the tragedy of the commons. Establishing private property rights using methods such as individual transferable quotas is occurring in several parts of the world to avoid the tragedy of depleted fish stocks. Well defined property rights, through the implementation of individual transferable quotas, ensure that fisheries internalize the cost and benefits of management decisions. Individual transferable fishing quotas have proven effective to increase conservation efforts and reduce overcapacity, which is often produced with increased legislation. Individual transferable quotas are not only a viable solution for reducing overfishing and preventing stock collapses, but the best solution available.
\end{abstract}

A ccording to Pauly et al., concern about the global state of fisheries and fish resources has increased in recent years, with global catches declining since the late 1980's. ${ }^{12}$ Fish resources have long been plagued by their open access nature, encouraging overcapacity and overexploitation. Cochrane states that marine resources are widely threatened by overfishing, leading to many of the world's fish stocks being fully or over-exploited. ${ }^{4}$

The purpose of this paper is to examine mistakes made in the past regarding fishery policy, using the collapse of the Atlantic cod fishery as an example, and evaluate viable solutions to prevent this tragedy from repeating. The establishment of private property rights through individual transferable quotas has been successfully implemented in several fisheries throughout the world with excellent results. Individual transferable quotas are not only a viable solution for reducing overfishing and preventing stock collapses, but the best solution available.

This paper will review the collapse of the Atlantic cod fisheries, describe the institutional and policy context, and examine the causes, conflicts and controversies of this catastrophe. It will then present and evaluate the free market perspective of this issue and conclude with recommendations for the future.

Tietenberg describes open access resources as "resources for which access is unrestricted". 14 Open access resources are characterized by non-exclusivity: they can be exploited by anyone, and divisibility: the capture of part of the resource one takes from the amount available from others. In the presence of sufficient demand, unrestricted access in open access markets will cause the resource to be overexploited. ${ }^{14}$ Unlimited access to a resource destroys the incentive to conserve, and thus open access resources have become known as the "tragedy of the commons". Garrett Hardin's "tragedy of the commons" metaphor is commonly invoked to describe to troubled state of the world's fisheries. ${ }^{8,9,12}$ Unlimited access to a commercial valuable species will typically result in overexploitation. Furthermore, this overexploitation results in overcapitalization, depressed incomes for fishermen, and depleted fish stocks. ${ }^{8}$ In simple terms, Gordon describes the open access fisheries as having "too many boats chasing too few fish". 6 
Table 1: Landed Value of Groundfish Catch in Canada from 1990 to 2002

\begin{tabular}{|l|r|}
\hline Year & Value of Catch \\
\hline & \$ thousand CND \\
\hline 1990 & 474,251 \\
\hline 1991 & 499,530 \\
\hline 1992 & 415,092 \\
\hline 1993 & 297,818 \\
\hline 1994 & 252,388 \\
\hline 1995 & 229,018 \\
\hline 1996 & 230,190 \\
\hline 1997 & 261,374 \\
\hline 1998 & 292,497 \\
\hline 1999 & 332,471 \\
\hline 2000 & 311,058 \\
\hline 2001 & 297,923 \\
\hline 2002 & 287,692 \\
\hline
\end{tabular}

Source: Created from data collected from Statistics Canada (2004)

Notes: Landed value refers to the monetary value of the fish caught. Groundfish refers to fish that generally feed and dwell near bottom of the ocean; this includes cod, haddock, pollock, redfish, halibut, and flounder. This data was complied by examining landed value data obtained from Statistics Canada. All of Canada was chosen to display how much the collapse of the Atlantic Groundfish stocks had on the overall amount of fish catch in the whole country, as well as illustrate that the downward trend of decreasing fish stocks is not unique to Atlantic Canada but to the whole country.

\section{The Collapse of the Atlantic Cod Fisheries: An Overview}

Brubaker reports that on July 2, 1992 Canada's fisheries minister banned cod fishing off the northeast coast of Newfoundland and off the southern coast of Labrador. ${ }^{3}$ One of the richest cod stock in the world had collapsed. Brethes adds that the moratorium on northern cod marked and a disaster for virtually all of Canada's Atlantic groundfisheries. $^{2}$ In the following year the Federal government limited the cod fishery in the northern and southern regions of the Gulf of St. Lawrence, Nova Scotia's east coast, and closed it entirely off to Newfoundland's south coast. Brubaker states that this was followed by further reductions and new moratoriums on cod and a variety of other economically important species of groundfish such as redfish, white hake, American plaice, turbot and witch flounder. ${ }^{3}$ Groundfish refers to fish that generally feed and dwell near the bottom of the ocean; this includes the species listed above as well as haddock, pollock, and halibut.

According to Brubaker, the collapse of the Atlantic groundfish stocks was an ecological, economic, and social catastrophe. ${ }^{3}$ Groundfish hauls in the 1980s averaged a landed value of $\$ 345$ million and a considerably higher processed value. The economic value of groundfish landings in Canada had been declining steadily since 1978. In 1991 the value of the total landings of all groundfish in Canada was $\$ 499,530,000$ and had declined to $\$ 287,692,000$ in 2002, as presented in Table 1. According to Gus Etchegary, former chairman of the Fisheries Council of Canada and former president of Newfoundland's largest fishing and processing company, had catches off Newfoundland and Labrador not declined in the preceding 25 years, they would have had an annual export value of $\$ 3$ billion by $1997 .^{3}$ The fishery closures resulted in 40,000 fishermen and fish processors losing their jobs and created social turmoil throughout Atlantic Canada. ${ }^{3}$

Equipped with high powered, all season factory trawlers, and sonar equipment, annual cod catches tripled from an annual average of 500,000 metric tons in the first half of the century $1,475,000$ metric tons in $1968 .{ }^{3}$ However, these immense catches would soon diminish; by 1978, they decreased to just 404,000 metric tons. ${ }^{3}$ The establishment of the 200 mile Exclusive Economic Zone in 1977 extended Canada's jurisdiction, creating hope that the stocks would recover as a result of decreased foreign fishing actives. ${ }^{3}$ However, annual cod catches decreased from 508,000 metric tons in 1982 , to 461,000 metric tons in 1998 , and to only 183,000 metric tons in 1992. This downward trend was not unique for cod; it was occurring for all economically valuable Atlantic groundfish species and continues to decrease today. In 1990, total live weight of groundfish caught in Atlantic Canada totaled 791,620 metric tons. This amount decreased each year to only 257,217 metric tons in 2002. This downward trend is illustrated in Figure 1. This figure appears to illustrate that the amount of caught groundfish leveling off (instead of decreasing), however this figure uses value of landed catch, so even though the catch is decreasing, the increase in price is accounting for the appearance of leveling off. Data from all of Canada was chosen to display how much the collapse of the Atlantic Groundfish stocks had on the overall amount of fish catch in the whole country, as well as to illustrate that the downward trend of decreasing fish stocks is not unique to Atlantic Canada but to the whole country.

\section{Encouraged to Over-fish: Failed Policy and Management System}

According to Brethes ${ }^{2}$ this crisis appeared in the context of a seemly effective management policy, at least since 1977, 


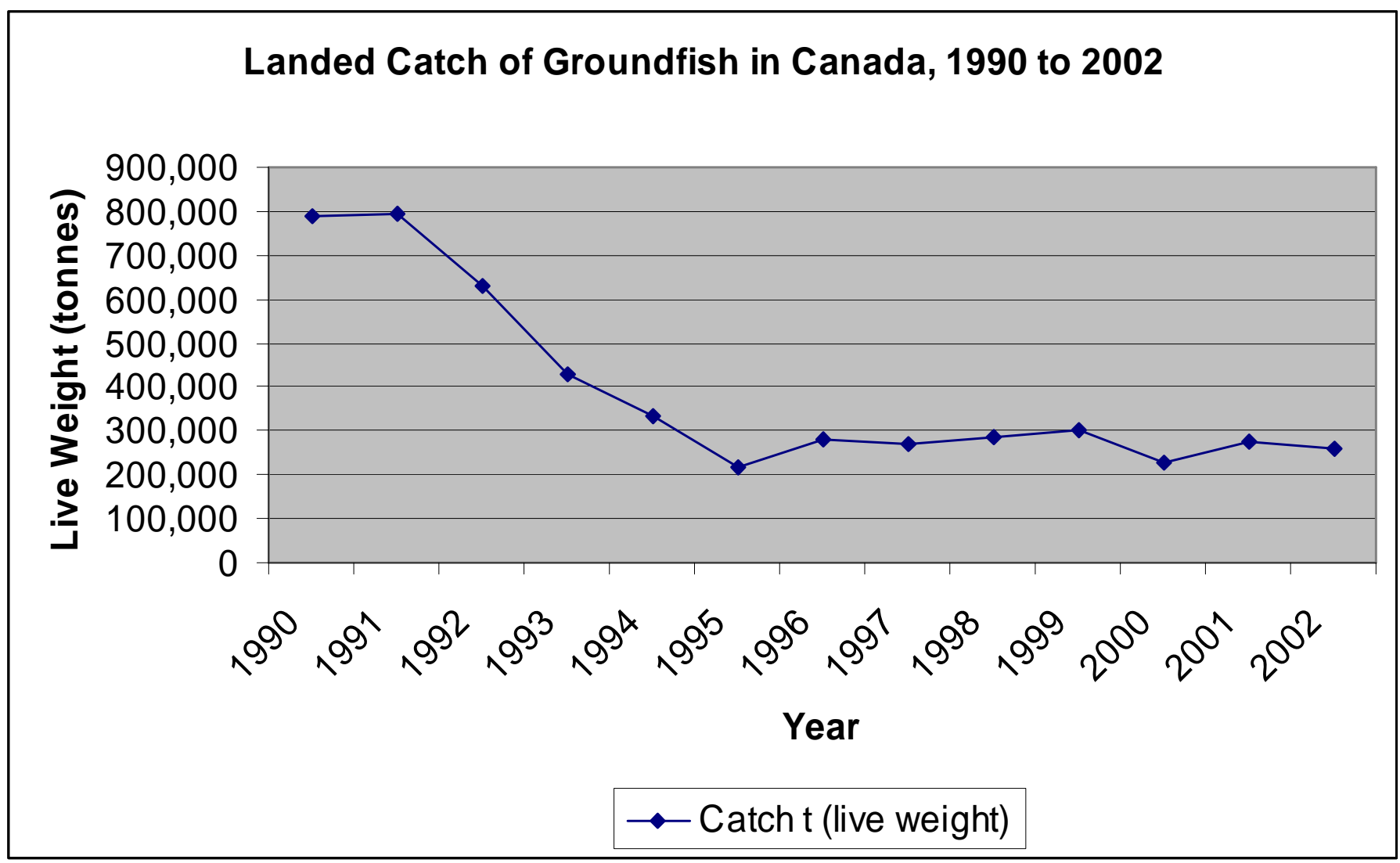

Figure 1: Landed Catch of Groundfish in Atlantic Canada from 1990 to 2002

Source: Created from data collected from Statistics Canada (2004)

Notes: Live Weight is measured in metric tons. "Catch $t$ " in the legend represents Catch measured in metric tons. Landed value refers to the monetary value of the fish caught. Groundfish refers to fish that generally feed and dwell near bottom of the ocean, this includes cod, haddock, pollock, redfish, halibut, and flounder. This was compiled using data from the Statistics Canada. All of Canada was chosen to display how much the collapse of the Atlantic Groundfish stocks had on the overall amount of fish catch in the whole country, as well as illustrate that the downward trend of decreasing fish stocks is not unique to Atlantic Canada but to the whole country.

when the Exclusive Economic Zone was declared, implemented by the Department of Fisheries and Oceans using Total Allowable Catches. Total Allowable Catches were adjusted each year to allow the matching of harvesting level to the capacity of the stocks and were adjusted by gear, vessel, area and species. These measures were designed to ensure long term sustainability of the resource. Unfortunately, the end result was a complex set of management rules which were exceedingly difficult to monitor and police.

According to Caddy et al., ${ }^{4}$ until 1992, scientists suggested a Total Allowable Catches level for each groundfish stock, which was the quota that fishers where allowed to catch in a given year based on weight. While using the best available techniques and technology, scientists became too confident in their tools to be suspicious about data sets. In addition, Caddy et al. state that scientists relied too heavily on supplementary data sets, such as catch rates of offshore fleets, which were unsustainably high. ${ }^{4}$ Stock levels were grossly overestimated leading to Total Allowable Catches that were set too high, inducing an intolerable fishing mortality. ${ }^{4,11,2}$

Additionally, according to Brethes, ${ }^{2}$ an increase in fishing capacity, which refers to the harvesting capacity of a fishery, contributed to the depletion of the Atlantic cod fishery. The increase in capacity was subsidized by both federal and provincial governments after the implementation of the 200 mile Exclusive Economic Zone in 1977, to replace foreign fishing capacity and to build a strong national fisheries industry. ${ }^{2}$ Another type of capacity which contributed to the depletion of the Atlantic cod fishery is processing capacity. The processing sector is under 

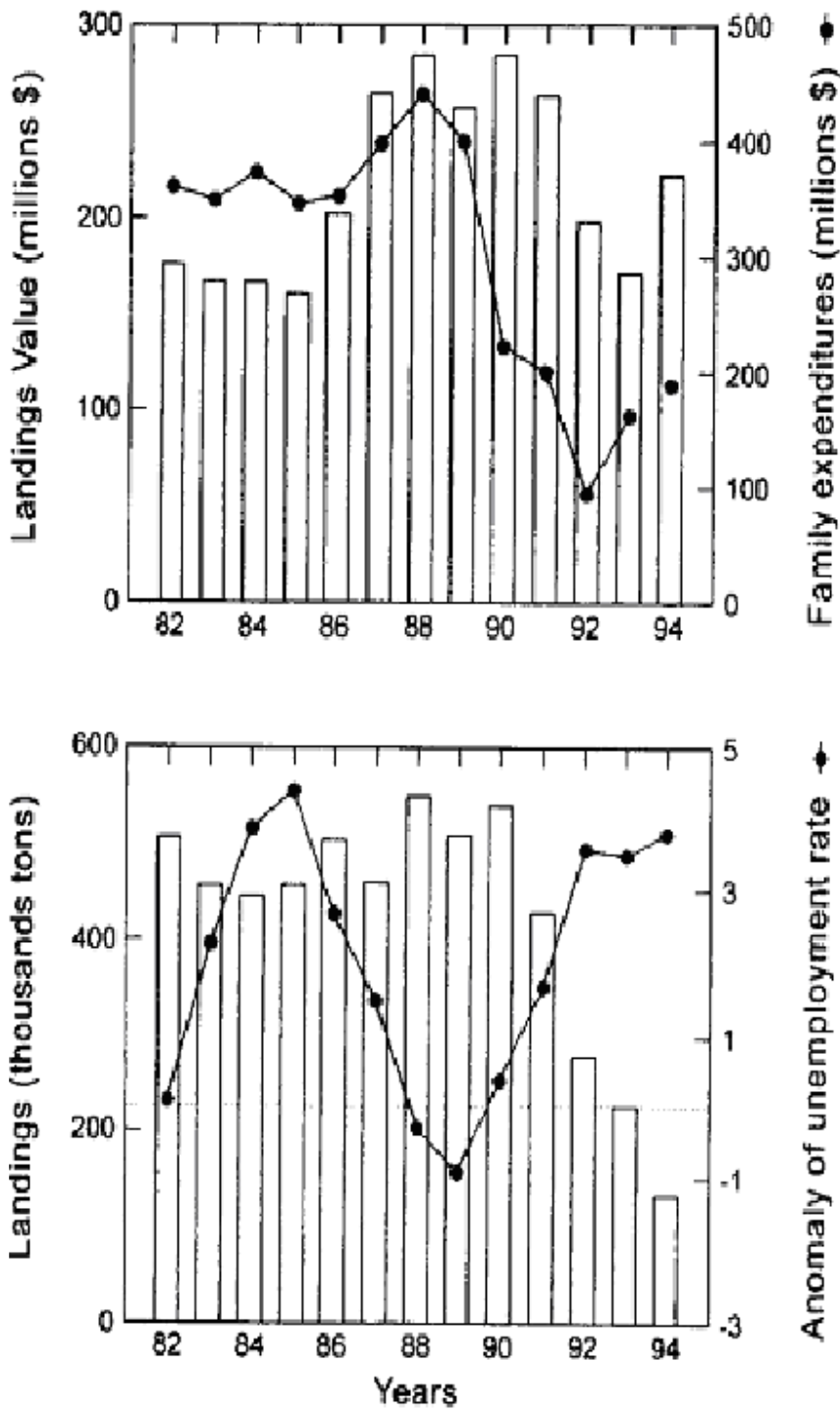

Figure 2: The Relationship between the Value of Groundfish Landings and Family Expenditures and Between the Value of Groundfish Landings and Unemployment in Newfoundland, Canada from 1982 to 1994

\section{Source: Taken from Brethes (1998)}

Notes: The bars represent the value of groundfish landings in Atlantic Canada and the line represents family expenditures in the first graph and anomaly of unemployment rate in the second graph.

provincial jurisdiction. The provincial governments encouraged the construction of numerous processing plants in coastal communities to increase employment rates.

Consequently, the increased processing capacity increased the pressure on the harvesting sector to feed the plants and meet market demand. ${ }^{2}$

Brubaker declares that the Federal government's primary objective was described in the 1970 Economic Policy for the Fisheries: maximizing employment in the fishing industry. ${ }^{3}$ In 1976, the Department of the Environment's Policy for Canada's Commercial Fisheries declared that fisheries management would be guided not by biological factors but by economic and social issues. Federal and provincial governments implemented numerous assistance programs for fishermen and fish processors. Brubaker goes on to say that subsidies increased over the years, but they were drastically enlarged after the 200 mile Exclusive Economic Zone was introduced. ${ }^{3}$ Loans were granted to fishermen at concessionary interest rates to encourage purchases of larger boats and more sophisticated equipment. The governments also assisted fishermen and fish processors through tax exemptions for fuel and equipment, by buying processing companies, and by subsidizing workers with various unemployment programs. ${ }^{3}$ Brubaker estimates that public expenditure on the Atlantic fisheries totaled $\$ 8$ billion during the 1980's. ${ }^{3}$ Introduced in the 1950's, the unemployment insurance program became increasingly more benevolent. In 1971, six weeks of fishing qualified for five weeks of benefits; by 1976 eight weeks of fishing qualified for 27 weeks of benefits. ${ }^{3}$

In Newfoundland, a province where the cod fishery had been the backbone of the economy, the most government assistance was provided. ${ }^{2}$ Figure 2 illustrates the relationship between fish and the economy in Newfoundland. It illustrates the negative correlation between the level of employment and volume of landings. ${ }^{2}$ According to Brubaker, economists at Memorial University calculate that, between 1981 and 1990, federal and provincial net outlays for Newfoundland's fisheries totaled \$3 billion, far exceeding the value of the catch. ${ }^{3}$ Of this, approximately half was in the form of unemployment insurance benefits. According to Brubaker, by 1990 Newfoundland's fishermen were receiving $\$ 1.60$ in benefits for every dollar they earned in the fishery. ${ }^{3}$

The unemployment insurance granted by the governments accelerated the groundfish stock collapse. The inflated workforce put increasing pressure on the stocks. In Newfoundland, the number of inshore fishermen increased by 53 per cent in the seven years following the introduction of unemployment insurance, even though the average catch fell by 50 per cent. ${ }^{3}$ Both scientists and fishermen warned the politicians that the fisheries could not expand at this rate, and the increased fishing was depleting the stocks. Despite warnings of overcapacity, the industry grew rapidly. ${ }^{3}$

The economic pressures had effects on setting the Total Allowable Catches for stocks, and were frequently set at the highest margin of the interval recommended by scientists. ${ }^{2}$

Overestimated cod stocks, thus exaggerated Total Allowable Catches, paired with increased fishing capacity, lead to the depletion of the Atlantic cod fisheries. Figure 3 illustrates the relationship between the biological advice (the bars), the Total Allowable Catches (full line) and the actual catches (dotted line) for the cod stocks in Atlantic Canada. Further, the increased fishing capacity coupled with powerful technology left the fish "no place to hide."2 The 


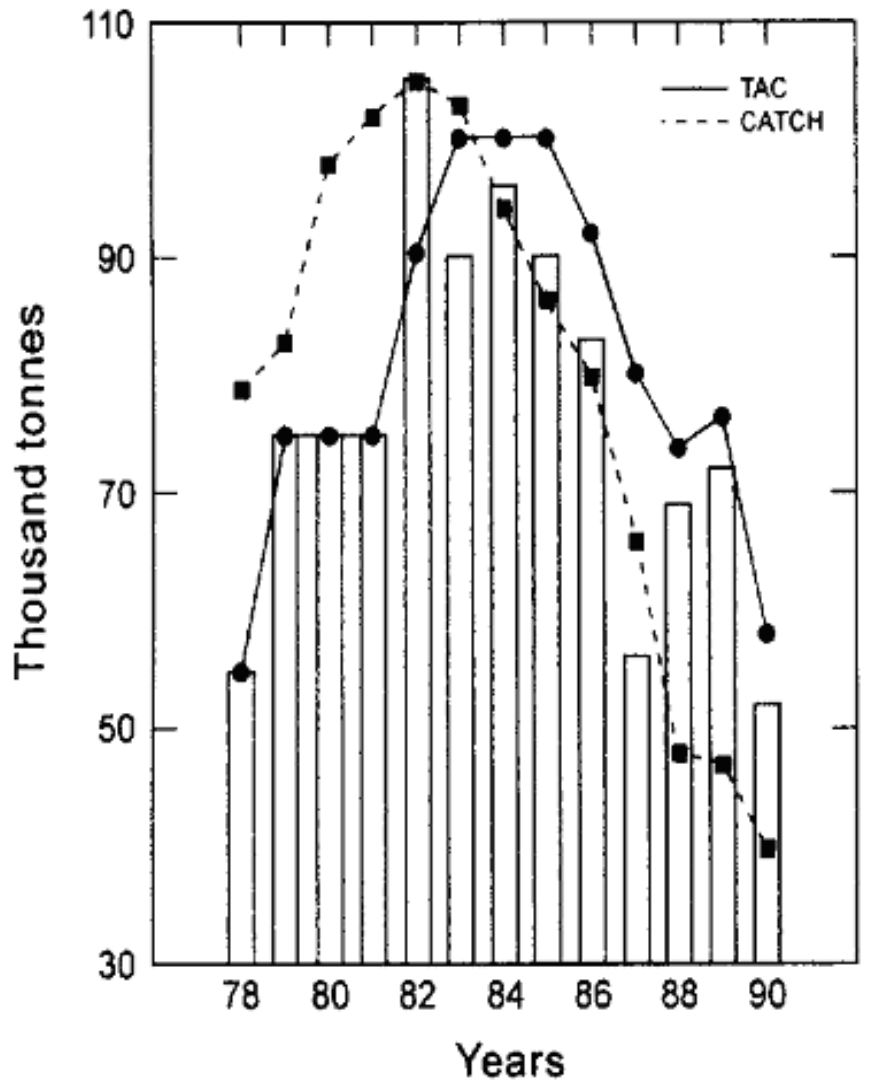

Figure 3: The Relationship between Biological Evidence, the Total Allowable Catch and the Actual Catch of Groundfish in Atlantic Canada from 1978 to 1990

\section{Source: Taken from Brethes, 1998}

Notes: The biological evidence is illustrated by the bars, the solid line represents the Total Allowable Catches and the dotted line represents the actual catch.

disappearance of refuge areas led to the decline of any buffer biomass that could help the rebuilding of stocks. Buffer mass is the required amount of fish necessary to rebuild stocks to previously high levels, so if this decreases then the stocks may not be able to recover.

\section{How Did This Happen? The Controversial Answer}

The cause of the collapse was a highly debated and controversial subject. The Department of Fisheries and Oceans placed blame on forces beyond their control, including cold water temperature and predation by seals. According to Brubaker, ${ }^{3}$ both Department of Fisheries and Oceans scientists and independent scientists published numerous papers documenting the role of overfishing in the collapse, sighting environmental factors as only minor roles, however the Department of Fisheries and Oceans barely mentioned overfishing in its 1995 overview of the causes stock collapses.

R. Myers, J. Hutchings and N. Barrowman, highly respected fisheries scientists, describe the primary factor of the collapse of cod stocks in their controversial paper Why do Fish Stocks Collapse? An Example of Cod in Atlantic Canada. Myers et al. directly contradicted and discredited the Department of Fisheries and Oceans' explain of the collapse. They conclude:

\begin{abstract}
"The population abundance was overestimated and the fishing mortality was underestimated. A large overcapacity in the fishing fleet allowed the potential for very high fishing mortality. The decline in the populations and the high fishing mortality were not recognized because of statistical bias and over-reliance on commercial catch-per-unit-effort data that were not proportional to the true abundance. As the population declined, fishing mortality increased and the populations were reduced to the point of commercial extinction". ${ }^{11}$
\end{abstract}

This conclusion hastily put an end to the debate. The blame was correctly laid on overfishing due to inadequate policy.

\section{Establishment of Private Property Rights through Individual Transferable Quotas}

Gordon's influential paper on open access exploitation identifies the fundamental cause of the overexploitation of fisheries resources as the absence of resource ownership, or poorly defined property rights. ${ }^{6}$ According to Homans et al., ${ }^{9}$ Gordon's paper has had paramount influence on the way economists view the "fisheries problem" and its solution, and has been one of the most enduring and widely cited paper in natural resource economics. In practice, the most recurrent property rights-based solutions involve individual transferable quotas, whereby fishermen hold a right to a share of biologically determined Total Allowable Catches. ${ }^{9}$

According to Anderson and Leal, well defined property rights are the heart of free market environmentalism. They state that

$$
\begin{aligned}
& \text { "...free market environmentalism emphasizes the } \\
& \text { positive incentives associated with prices, profits, and } \\
& \text { entrepreneurship, as opposed to political } \\
& \text { environmentalism, which emphasizes negative incentives } \\
& \text { associated with regulation and taxes." }
\end{aligned}
$$

Well defined property rights, through the implementation of individual transferable quotas, ensure that fisheries internalize the cost and benefits of management decisions. Fishery owners realize that if they harvest unsustainable catches and destroy their resource they will bear the costs and consequences of their actions. According to Brubaker, exclusive, permanent property rights let fishery owners benefit from their conservation effort, creating incentives to correctly monitor and conserve their stocks and habitats. ${ }^{3}$ 
According to Leal, ${ }^{10}$ individual transferable quotas increase conservation because initiatives to sustain the health of a fishery can pay off immediately by increasing the value of the quota. Individual transferable quotas allow fishery owners to base their decisions on their own detailed knowledge of local stocks, fish behaviours and environmental conditions. Brubaker states that this kind of knowledge is important because it is specific to their time and place, allowing them to chose and implement actions quickly. $^{3}$

According to Leal, individual fishing quotas have proven effective to reduce overcapacity, which is often produced with increased legislation. ${ }^{10}$ Since legislation often placed time restrictions on the fishing season, overcapacity became a problem due to the incentives this type of legislation created, such as the biggest, fastest boats to catch the most fish in the allotted time and fishing during unsafe conditions. With individual transferable quotas the season can remain open for much longer, allowing fishers to fish when and where they choose, thus reducing incentive to invest in unnecessarily large and fast boats. Leal reports that safety can improve as a result of individual fishing quotas as fishers will no longer have incentive to fish in bad weather. ${ }^{10}$ Leal states that because the individual transferable quotas are transferable, quota holders can adjust the size of their operation by buying and selling the right to their quota. ${ }^{10}$

\section{Evaluation of Individual Transferable Quotas: Will they work?}

There is an increasing number of programs where individual transferable quotas have been implemented successfully, producing a number of positive results including reducing overfishing. The earliest examples of successful implementation of this strategy took place in Iceland and New Zealand in the early 1980s. ${ }^{9}$ Brubaker compares the Icelandic and Canadian fisheries in the 1970's. ${ }^{3}$ Even though Atlantic Canada landed and processed only 82 per cent as many fish and produced a lower quality product, there were 10 times as many Canadian fishermen, 17 times more boats and twice the plant workers. Private fisheries around the world including but not limited to salmon fisheries in Iceland, inland fisheries in England, oyster beds in the United States and quota based fisheries in New Zealand verify that property rights promote sustainable fishing behavior. Clearly, fishermen have more incentive to conserve and monitor their stocks and invest in their habitat with a privately owned fishery.

Leal reports that the introduction of individual transferable quotas has had significant positive effects on the halibut fishery in Alaska, including reaching the primary goal of creating a sustainable fishery. ${ }^{10}$ Leal notes that, since the implementation of the individual transferable quotas, managers were able to extend the season from one day openings to eight month long operations. ${ }^{10}$ The longer season has increased the availability of fresh fish and increased the price per pound. It has also increased safety due to reduced incentive to fish in bad weather. According to Leal, the Total Allowable Catches are no longer routinely exceeded, less gear is lost, and less fish is destroyed on the trip. ${ }^{10} \mathrm{By}-$ catch was a problem in this area before the implementation of individual transferable quotas, but has been reduced by over $80 \%$ by allowing the seasons of halibut to overlap with the catching season sablefish.

Leal also reports that the new system has also increased species conservation; as an example, investments that were used for overcapacity are now used for selective harvesting. ${ }^{10}$ This example illustrates a number of positive effects individual transferable quotas can have on a fishery, including the primary objective of creating a sustainable fishery by reducing overfishing. Both of these examples show that the establishment of private property rights through individual transferable quotas have been successfully implemented in the past with excellent results; therefore individual transferable quotas are a viable solution for reducing overfishing and preventing stock collapses.

\section{A Sustainable Future in Fisheries: What is the Best Solution?}

There is general agreement that the world's fisheries are plagued by poor economic profitability, low stock abundance, discarding, by-catch and fishing impacts on marine ecosystems. ${ }^{8}$ Furthermore, there is broad agreement that fisheries should evolve towards lower fishing effort, higher stock abundance, less impact on marine ecosystems and higher economic profitability. ${ }^{8}$ However, there is less agreement on how to get to this desired state from where fisheries are today. Different disciplines point to different solutions, and there are differences within these disciplines. ${ }^{8}$ One point of universal agreement is that subsidies for vessel construction encourage overcapitalization, therefore are major contributors to non-sustainability. ${ }^{8,12}$ Subsidies, which amount to $\$ 2.5$ billion for the North Atlantic alone, intensify problems arising from the open access aspects of fisheries. ${ }^{12}$ It is obvious that a drastic reduction of overcapacity will have to occur if fisheries are to acquire sustainability. ${ }^{12}$

In response to growing awareness of the failures of fisheries management, there have been widespread attempts to improve its performance, most notably by greater emphasis on assessing the uncertainty in stock assessments and management systems as well as considering these in decision making, including the involvement of fishers and other interest groups in the management process. ${ }^{4}$ According to Hilborn, understanding the behaviour of fishermen is a key ingredient to successful fisheries management. ${ }^{8}$ It has also been suggested that fisheries policy makers should fully consult fishermen in the development of fisheries rules and regulations, and give them a say in the implication of those rules. ${ }^{7,5}$ The Federal government appeared to regulate the fisheries in every way possible, but nothing seemed to prevent the over-exploitation of this important resource. ${ }^{10}$ 
According to Leal government regulations have placed restrictions on the size and power of fishing vessels, the types of fishing gear, the times and area in which fishing is allowed, the number of trips a single vessel can make in a season, the amount of fish vessels can land per trip, and the size of fish allowed to be removed from the sea. ${ }^{10}$ These restrictions rarely worked and overfishing continued. Establishing private property rights seems to be the most viable solution to accomplish what direct regulation is unable to: sustainable fisheries. Furthermore, as seen with the Myers example, the government did not take responsibility for attributing to the collapse of the Atlantic cod fisheries. This lack of accountability is what individual transferable quotas would avoid.

Government control of fisheries desperately tried to prevent overfishing but their policies and legislation only created negative incentives and did not prevent the over exploitation of many economically important fisheries including Atlantic cod. Based on the information and examples presented in this report the implementation of individual transferable quotas can have many positive effects on fisheries, including the primary objective of a sustainable fishery: reducing overfishing. The establishment of private property rights through individual transferable quotas has been successfully implemented in the past with excellent results; therefore individual transferable quotas are not only a viable solution for reducing overfishing and preventing stock collapses, but the best solution available.

\section{REFERENCES}

1. Anderson, T., D. Leal. 2001. Free Market Environmentalism. Revised Edition. Palgrave: New York.

2. Brethes, J.C. 1998. The Canadian Atlantic groundfish experience and the constraints to the conservation of fisheries resources: a perspective. Ocean \& Coastal Management 39 (1998) 135-150.

3. Brubaker, E. 2000. Unnautral Disaster: How politics destroyed Canada's Atlantic Groundfisheries. In E. Anderson, ed. Political Environmentalism. Standford, CA: Hoover Institution Press.
4. Caddy J.F., and K.L. Cochrane. 2001. A Review of fisheries management past and present and some future perspectives for the third millennium. Ocean and Coastal Management. 44 653- 682.

5. Felt, L., Neis, B., and B. McCay. 1997. Comanagement. In J. Boreman ed. Northwest Atlantic Groundfish: Perspectives on a Fishery Collapse. American Fisheries Society.

6. Gordon H.S. 1954. The economic theory of a common property resource: the fishery. Journal of Politics and Economics. 63 116-124.

7. Hall-Arber, M., and A.C. Finlayson. 1997. Role of local institutions in groundfish policy. In J. Boreman ed. Northwest Atlantic Groundfish: Perspectives on a Fishery Collapse. American Fisheries Society.

8. Hilborne, R. 2007. Managing fisheries is managing people: what has been learned?" Fish and Fisheries. 8 285- 296.

9. Homans, F.R., and J.E. Wilen. 2005. Markets and rent dissipation in regulated open access fisheries. Journal of Environmental Economics and Management. 49 381404.

10. Leal, D. 2006. Saving fisheries with free markets. Leal Milken Review.

11. Myers, R.A., Hutchings J.A., and N.J Barrowman. 1997. Why do fish stocks collapse? The example of cod in Atlantic Canada." Ecological Applications. 7 91-106.

12. Pauly, D., Christensen, V., Guenette, S., Pitcher, T., Sumaila R., Walters, W., Zeller, D. 2002. Towards sustainability in world fisheries. Nature. 418 689-695.

13. Statistics Canada. n.d. Landed Catch and Value 1990 to 2002 (table).Department of Fisheries and Oceans, Statistical Services, www.Department of Fisheries and Oceansmpo. gc. ca/ communic/ statistics/ commercial/ andings/ seafisheries/ index_e.htm (accessed July 8, 2004).

14. Tietenberg, T. 2003. Environmental and Natural Resource Economics. Sixth Edition. Addison Wesley: Boston. 